\title{
Social Engineering Strategy of Entrepreneurship Behavior of Indonesian Migrant Workers During the Placement Period
}

\author{
Submitted on $2 / 12 / 18,1^{\text {st }}$ revision $12 / 1 / 19,2^{\text {nd }}$ revision $17 / 2 / 19$ accepted $25 / 3 / 19$
}

\author{
Izza Mafruhah ${ }^{1}$, Waridin Waridin², Deden Dinar Iskandar ${ }^{3}$, Mudjahirin \\ Thohir $^{4}$
}

\begin{abstract}
:
Purpose: The main objective of this research is to formulate a social engineering strategy of entrepreneurship behavior of Indonesian workers.

Design/Methodology/Approach: The study used a sequential mixed method with regression by analyzing (1) factors that influence their entrepreneurship behavior, (2) factors that influence their remittance delivery, and (3) social networking patterns that influence their characteristics and motivation to be independent.

Findings: The results showed that training, marital status, and work experience in the home country were factors influencing entrepreneurship motivation, while training, remittance recipients, origin and determinants of remittance utilization affected the amount of remittances sent. In addition, social networking shows that motivation to be independent is influenced by training in both hard and soft skills and assistance in both institutional and capital.

Practical Implications: This research is expected to be able to provide input to the government, especially the central government as the regulator to formulate regulations in the form of legislation, especially for increasing the human capital of Indonesian migrant workers from the time of pre-placement, placement and through to post-placement.

Originality/Value: The social engineering model proposed that is integrated with the structured curriculum and materials followed by ongoing mentoring with a learning group system or Community Learning will encourage migrant workers.
\end{abstract}

Keywords: Migrant worker, social engineering, entreprenership, mixed method.

JEL code: $G 21$, G29.

Paper type: Research article.

\footnotetext{
${ }^{1}$ Faculty of Economics and Business, Sebelas Maret University, email: izza_wisnu@yahoo.com

${ }^{2}$ Faculty of Economics and Business, Diponegoro University, Semarang 50257, Indonesia. Jalan Erlangga Tengah 17 Semarang 50421. Tel/ Fax: +62-24-8442273

${ }^{3}$ Faculty of Economics and Business, Diponegoro University, Semarang 50257, Indonesia.

${ }^{4}$ Faculty of Humanities, Diponegoro University, Semarang 50257, Indonesia
} 


\section{Introduction}

Migrant workers are an interesting issue in the socio-economic field because they are directly related to the problems of poverty, employment, unemployment, human capital, entrepreneurship, family welfare, regional economy and foreign relations (Williams, 2009). Migrant labor problems, in general, can be divided into three stages: pre-placement, placement, and post-placement. The three stages are interrelated, so that problems at one stage will affect the other stages. The placement period is the most crucial period in determining the success of migrant workers to improve their welfare in the future. However, so far there is still no research that focuses on this stage, and this research aims to fill this gap. Migrants who have returned to their home countries have more value because they have worked in more developed countries both in terms of technology and the production process so that they are able to overcome human capital constraints. On the other hand, migration also has a static or even negative effect on human capital, where the skills and level of education of a migrant in the destination country remain unchanged or even decline below their appropriate level of education, skills and capacity (Mattoo \& Neagu, 2006).

Increasing the ability of migrant workers and changing their mindset requires an integrated development of internal and external factors (Riswanto, 2018). This change is known as social engineering, meaning that changes in social conditions that do not occur naturally but involve interference from other parties or manipulations that aim to influence change (Rahmat, 1999). Social change is done because of the difference between das sollen (the conditions that should be) with das sein (real conditions). Social change involves collective action to solve social problems which will be followed by changes in the shape and function of the community groups, existing institutions, and the social order that has been formed (Geels, 2004). The process of social change is grouped into three types: evolution, revolution and reform. Social change is carried out through three models: (1) Normative-reeducative, a change strategy that is carried out by changing the community paradigm through repetitive learning, (2) Persuasion, a change made through the formation of public opinion, and (3) People's power, a social change through power. The main objective of this research is to formulate a social engineering strategy of entrepreneurial behavior of Indonesian Migrant Workers (IMW) at the time of placement using the workers community in Hong Kong as the study case.

\section{Literature Review}

Fisher in Mankiw (2008) stated that consumers have two periods of consumption during their lives. The first period comes from current income (at the time), while the second period is current consumption (at that time) added with precautionary savings or accumulated savings for the first period involving interest. Revenue in this concept is the amount of income received by everyone in the community, 
including the income earned without doing any activities. Individual income that can be spent is called Disposable Income (Yd), which is income after tax. Yd will be allocated into two main variables: consumption and savings (Mankiw, 2008). This study uses the concept of consumption pattern of Permanent Income Life Cycle Hypothesis, or PI-LCH (Figure 1) because the income of migrant workers is permanently obtained while working in Hong Kong, which is limited by the contract period, but will be used throughout their lives. In Hong Kong, Permanent Income Life Cycle Hypothesis (PI-LCH) occurs because at the time of placement, migrant workers obtain Permanent Income and must manage it to become a lifetime income (during post placement). This condition will lead to different consumption behavior.

Figure 1. Permanent Income Life Cycle Hypothesis

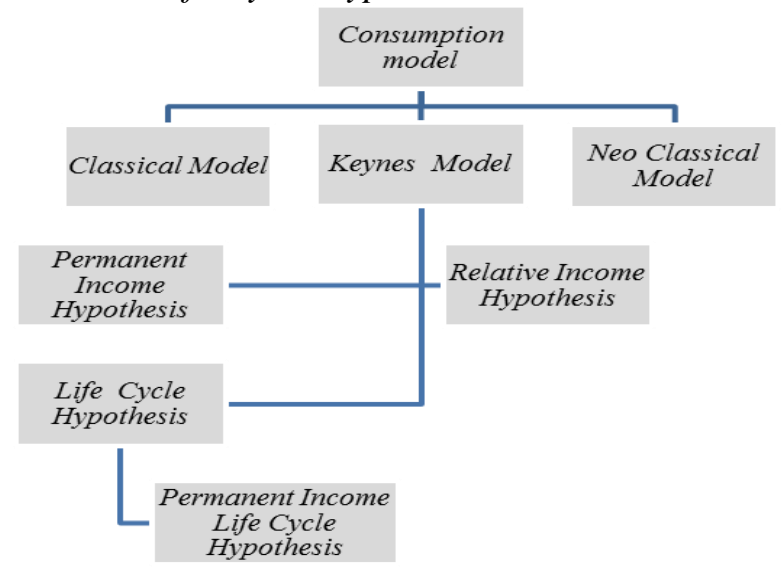

The life cycle hypothesis ( $\mathrm{LCH})$ states that humans experience three different times: children, adults, and elderly (Tin, 2000). In these three lifetimes, consumption patterns can be different. Modigliani et al. (1963) try to explain consumption and income patterns based on these cycles. This concept hypothesizes that consumers will maximize satisfaction throughout life with wealth constraints. The amount of income during the period of life can come from permanent income, temporary income, income from assets and expected income. The income is then used for consumption. If part of the income is not used for consumption, this will be saved. Changes in the amount of income will determine the similarity of the budget and preferences. In the household scale and based on life cycle theory, the factors that determine income and consumption will also determine the amount of savings (Efriyani, 2008).

One of the main characters shown in the change of individual motivation for entrepreneurship is saving which is a conscious allowance not just remnants of consumption. This study uses marginal propensity to saving as a criterion for changes in mindset and behavior of Indonesian labor migrants. Rational Choice Theory (RCT) is one theory that supports behavior change. RCT is an economic principle that assumes that individuals always make wise and logical decisions that 
give them the highest number of personal utilities. This theory assumes that everyone tries to be active in maximizing their utility and minimizing risk consistently. The main basis of this theory is that humans use rational calculations to make decisions. RCT can also be interpreted as an axiomatic system that provides a basis for making individual decision choices. The axiom of this theory must fulfill the requirements of consistency, transitivity, independence, continuity and monotony. Consistency requires individuals to be able to compile ranks that are interconnected with the same or unequal preferences (Sato, 2013).

One important postulate in rational choice theory is that all complex social phenomena are driven by individual human actions. This postulate is a fundamental principle of the statement that social change or social institution change is influenced by the rational decisions of individuals as a whole (Hardin, 2015). Rational choice theory is based on the premise of maximizing selfish individual utility, while organizational theory is based on the premise of an efficient function of the organization through the rationality of means in the organization. Economically, organizational theory forms an indirect relationship with rational choice theory. The organization will link rational choice theory from the micro level to the meso-level organization and as an aggregation method, especially with organizational changes due to changes in individual characteristics (Zey, 1997). This study uses rational choice theory as one of the main theories specially to bridge social engineering that starts from individual change.

RCT affects changes in mindset and behavior with gradual social engineering. This research attempts to change the mindset of migrant workers by manipulating their entrepreneurial behavior and empowerment. Entrepreneurship is an activity that is consistently carried out to convert promising ideas into profitable activities. Further research on entrepreneurs especially in the regional information system separates entrepreneurship features into three dimensions of social capital: structural, relational and cognitive. Entrepreneur is a mindset that is manifested in behavior that colors people's lives both economically and non-economically. Behavior is a set of human actions that are influenced by customs, attitudes, emotions, values, ethics, power, persuasion and or genetics. Behavior will be formed in the long term and affect the mindset and daily activities. A more modern understanding states that there has been a shift in entrepreneurial behavior which was originally top down to bottom up (Yoon et al., 2015).

\section{Material and Methods}

This study uses a sequential mixed method that combines quantitative methods with qualitative methods which are used sequentially. Regression analysis was used to answer the first and second objectives of this study. Meanwhile, to answer the third objective, qualitative analysis was used supported with ATLAS.ti. 
Data from the Consulate General of the Republic of Indonesia (KJRI) Hong Kong shows that the new placement and renewal of contracts in 2014 was 46,565, in 2015 was 47,107 and in 2016 was 46,533, so the total migrant workers in Hong Kong was 140,205 . This study used 150 respondents, but due to the issue of data validity only 115 respondents could be involved. This number is considered sufficient because of time and technical difficulties in sampling. Sampling was done by non-probability accidental sampling, and the sample was divided into two: migrant workers who attend and who do not attend training. Training includes all compulsory training conducted by KJRI except welcoming and exit program training.

Respondents were interviewed with a questionnaire guide and the results were then processed quantitatively and qualitatively. Some of these respondents will be selected as core respondents who will be informants for in-depth interviews. Researchers have approached the core informants and communicated with them intensely through WhatsApp, SMS, telephone and Facebook. Primary data sources were also obtained through in-depth interviews with the Consulate General of the Republic of Indonesia Hong Kong, Banking Institutions, Migrant Care Institutions and Institutions that provide training for Indonesian Migrant Workers in Hong Kong, the National Agency for the Placement and Protection of Indonesian Workers and the Ministry of Labor.

Regression Analysis Model for the First Objective:

$\mathrm{Tab}=\alpha_{0}+\alpha_{1}$ age $+\alpha_{2}$ edu $+\alpha_{3}$ Dori $+\alpha_{4} \mathrm{D}_{1}$ wid $+\alpha_{5} \mathrm{D}_{2}$ sing $+\alpha_{6}$ year_tki $+\alpha_{7}$ depart_cost $+\alpha_{8}$ dtrain $+\alpha_{9}$ dwork $+\mathrm{e}$

Notes: Saving = Monthly saving amount; Age = Current Age; Edu= Education; $D$ ori $=$ Dummy variables of the IMW areas of origin, Dummy Village $=0$ City $=1 ; Y_{-}$tki $=$ Years as IMW; Departure cost= The amount of costs incurred for placement; Dwid= Dummy variables of marital status; Dummy Widow $=1$, Others $=0$; Dsing $=$ Dummy variables of marital status, with benchmark Single $=1$, Others $=0 ;$ Dtrain $=$ Participation in training with dummy variables of training $=1$, no training $=0 ;$ Dwork $=$ Dummy variables of work experience domestically before becoming IMW, with work experience $=1$, and no work experience $=0 ; e=$ error term.

Regression Analysis Model for the Second Objective:

Rem $=\alpha_{0}+\alpha_{1}$ fam $+\alpha_{2}$ D ori $+\alpha_{3}$ depart_cost $+\alpha 4$ train $+\alpha_{5}$ reciv $+\alpha_{6}$ D1 useIMW $+\alpha_{7} \mathrm{D} 2$ useother $+\mathrm{e}$

Notes: Rem = Remittances sent every month; Fam = Number of IMW family dependents; Dorigin $=$ Dummy variables of the IMW areas of origin, with village $=0 ; D$ reciv $=$ Dummy variables of IMW relationship with remittance recipients; Dummy nuclear family (child / spouse $)=1 ;$ Dummy Extended Family $($ parent $/$ sibling $)=0 ; D$ useIMW $=$ Dummy determinants of remittance utilization; Dummy self-determined $=1$; Dummy determined through deliberations $=0 ; D$ useother $=$ Dummy determinants of remittance utilization,; Dummy Other Determinants = 1; Dummy Self-determined and determined through deliberations $=0 ; e=$ Error term. 


\section{Results and Discussion}

The most attractive destination countries for Indonesian labor migrants are Malaysia, Saudi Arabia, Taiwan and Hong Kong. The selection of the destination country is based on a number of reasons including religion, language, distance and income. The selection of Hong Kong as the location of this study was due to several advantages and disadvantages that would affect the Indonesian migrant workers such as:

a. The Hong Kong economy that drives the consumerism for Indonesian labor migrants

b. The Hong Kong government provides strong legal protection to foreign workers, including Indonesian labor migrants, so that problems related to labor migrants can be minimized.

c. Employment law in Hong Kong implements weekly holiday policy so as to allow for regular socialization and meeting forums both formal and informal for Indonesian migrant workers.

d. The Hong Kong government applies clear wage provisions similar to the determination of Minimum Wage in Indonesia so that the income of Indonesian migrant workers tends to be the identical.

e. The Consulate General and representatives of the Indonesian Ministry of Labor are relatively responsive in handling and facilitating Indonesian migrant workers in Hong Kong;

This affects the amount of savings allocated and the amount of remittances sent. Processing using regression of Least Squares Method obtained the following results

Table 1. Regression Results for the First Objective

\begin{tabular}{|c|c|c|c|c|}
\hline Variables & Coefficient & Std. Error & $\mathrm{t}$-Statistic & Prob. \\
\hline $\mathrm{C}$ & 2438161. & 921409.2 & 2.646122 & $0.0094 *$ \\
\hline AGE & -5534.482 & 20118.65 & -0.275092 & 0.7838 \\
\hline EDU & -42967.41 & 53749.77 & -0.799397 & 0.4259 \\
\hline$\overline{\text { ORI }}$ & 518135.2 & 295991.0 & 1.750510 & $0.0830 * *$ \\
\hline Year_TKI & -48043.07 & 39850.28 & -1.205589 & 0.2307 \\
\hline Departure_Cost & -0.000423 & 0.021466 & -0.019721 & 0.9843 \\
\hline DWid & 1272435. & 337277.9 & 3.772659 & $0.0003^{*}$ \\
\hline DSing & 147666.5 & 349728.2 & 0.422232 & 0.6737 \\
\hline DTRAIN & 1251469. & 254325.5 & 4.920736 & $0.0000 *$ \\
\hline DKERDN & -499570.4 & 254766.7 & -1.960894 & $0.0526 *$ \\
\hline R-squared & 0.334260 & \multicolumn{2}{|c|}{ Mean dependent var } & 2387140. \\
\hline Adjusted R-squared & 0.276648 & \multicolumn{2}{|c|}{ S.D. dependent var } & 1541827. \\
\hline S.E. of regression & 1311326. & \multicolumn{2}{|c|}{ Akaike info criterion } & 31.09461 \\
\hline Sum squared resid & $1.79 \mathrm{E}+14$ & \multicolumn{2}{|c|}{ Schwarz criterion } & 31.33462 \\
\hline Log likelihood & -1762.393 & \multicolumn{2}{|c|}{ Hannan-Quinn criter. } & 31.19202 \\
\hline F-statistic & 5.801900 & \multicolumn{2}{|c|}{ Durbin-Watson stat } & 1.395669 \\
\hline Prob(F-statistic) & 0.000002 & & & \\
\hline
\end{tabular}


Note: Dependent Variable: Saving Sample: 1115 Included observations: 114

Data processing results show that Constanta variable is significant, and there are three independent variables that are statistically significant at alpha level of 5\%, namely dtrain, djan, and dkerdn. The origin of Indonesian migrant workers is also statistically significant but at alpha level of $10 \%$. Respondents' participation in the training becomes one of the variables that influence the savings at IDR 1.251.469, which implies that there is a difference in the amount of savings allowance between respondents who attended the training and those who did not. Respondents who took part in the training had more savings amounting to IDR 1.251 .469 or equal with 80 USD.

The marital status variable with Dummy Widow $=1$ is significant, meaning that there is a difference in saving behavior between migrant workers who are widowed and those who are married and single. The coefficient value of 1.272 .435 means that there is a difference by more than IDR. 1,272,435 equal with 85 USD in the amount of widow savings compared to married and single savings. Work experience variable shows a significant result. The coefficient is $-499,570$ which means that there is a difference in the amount of savings between migrant workers who have worked and those who have never worked in the home country. Indonesian labor migrants who have worked have savings of less than IDR 499,570, equal with 35 USD - compared to those who have never worked. The results of the in-depth interview showed that those who had worked felt that income in Hong Kong was far higher than that in the home country, so they felt free to use it in the form of living costs or remittances. IMWs who have never worked in the home country tend to be more careful to use their money and save more.

Origin variable is also significant but at alpha level of $10 \%$. The coefficient is $518,135.2$ which means there is a difference in savings of more than IDR. 518,135.2 equal with 40 USD for migrant workers from the city. The reason for the explanation is related to the cultural difference between the village and city community. In the village community, a person is considered successful when he/she is able to build a good house, own a vehicle and find comfort or pleasure. For migrant workers from villages, building houses is a top priority, therefore some of their income will be sent to the village to build or renovate their houses. As for migrant workers from the city, the most important thing is how they are able to continue improving their lives. The results of the regression data processing with the saving variable shows that education, age, years as migrant workers, departure costs, and being single do not significantly influence the saving behavior.

Table 2. The results of processing factors that influence remittance

\begin{tabular}{|l|l|l|l|l|}
\hline Variable & Coefficient & Std. Error & t-Statistic & Prob. \\
\hline C & 3968033. & 735531.5 & 5.394783 & $0.0000^{*}$ \\
\hline FAM & -40092.15 & 123039.1 & -0.325849 & 0.7452 \\
\hline D ORI & -632112.7 & 335374.1 & -1.884799 & $0.0622^{* *}$ \\
\hline
\end{tabular}




\begin{tabular}{|l|l|l|l|l|}
\hline Departure_Cost & -0.007087 & 0.022621 & -0.313279 & 0.7547 \\
\hline DTRAIN & -1021358. & 297114.7 & -3.437588 & $0.0008^{*}$ \\
\hline DRECIV & 780265.6 & 304621.7 & 2.561425 & $0.0118^{*}$ \\
\hline USEIMW & -610321.9 & 345255.7 & -1.767739 & $0.0800^{*}$ \\
\hline USEOther & 274982.4 & 430657.7 & 0.638517 & 0.5245 \\
\hline R-squared & 0.262529 & Mean dependent var & 3079217. \\
\hline Adjusted R-squared & 0.214284 & S.D. dependent var & 1673125. \\
\hline S.E. of regression & 1483069. & Akaike info criterion & 31.32415 \\
\hline Sum squared resid & $2.35 E+14$ & Schwarz criterion & 31.51510 \\
\hline Log likelihood & -1793.139 & Hannan-Quinn criter. & 31.40166 \\
\hline F-statistic & 5.441502 & Durbin-Watson stat & 1.788190 \\
\hline Prob(F-statistic) & 0.000023 & \multicolumn{5}{l}{} \\
\hline Note: Dependent Variable: Remittance Sample: 1 115 Included observations: $: 115$ \\
\hline
\end{tabular}

Data processing shows that dtrain is significant, which means that there is a difference in the amount of remittances between respondents who attended the training and those who did not. Coefficient value of -1.021 .358 implies that respondents who participated in the training sent less remittances with a difference of IDR . 1,021,358, equal with 70 USD - compared to those who did not attend training.

Remittance recipients who are categorized into nuclear and extended families have a significant effect, meaning that there are differences in remittance sending behavior between migrants with nuclear families and those with extended families. The coefficient value is 780265.6, meaning that the IMW will send a larger amount by up to IDR. 780,265.6 equal with 55 USD to the nuclear family. These results indicate that Indonesian labor migrants give more trust to nuclear families compared to extended families, indicated by a large remittance gap.

The origin variable shows a significant influence on the alpha level of $6.2 \%$. This means that there are differences in behavior between respondents from villages and those from cities. The coefficient value is $-632,112.7$, meaning that city respondents send less remittances by IDR 632,112.7 equal with 45 USD compared to village respondents. This result is consistent with the previous regression results in which city respondents have more savings than village respondents. Respondents from villages send more remittances because finding income in the village is more difficult than that in the city.

The determinants of remittances utilization by IMW themselves (useIMW) also shows a significant effect at alpha level of $8 \%$, meaning that there is indeed a difference when determining the use of remittances. The coefficient value is 610,321.9, which implies that when the migrants decide themselves, the amount of remittances sent is less by IDR. 610,321.9, equal with 43 USD compared to decision by deliberation. This is because IMW knows exactly how much they need to send to meet the family's living needs every month, so they only sends as much as needed. 
The third objective in this study is to analyze the influence of entrepreneurship networks of Indonesian migrant workers. The main reason for Indonesian workers leaving overseas to become migrant workers is for economic reasons. The increasing number of Indonesian migrant workers raises many and varied problems from the beginning to the end. IMW issues are divided into three main stages: pre-placement, placement and post-placement. These three stages are interconnected. Research by Mafruhah show that the most problematic stage is the placement, but the problem actually starts at the pre-placement. Qualitative analysis was used to explain the preferences of Indonesian labor migrants and related parties to increase entrepreneurship with in-depth interviews with several informants consisting of Indonesian migrant workers, the Ministry of Manpower, Banking, and the Consulate General. These stakeholders are chosen as informants because they directly and indirectly relate continuously to Indonesian labor migrants and entrepreneurship development so that they understand the migrants characters.

The results of the in-depth interview are processed using the ATLAS.ti. The first step is to transcribe the results of interviews with informants. The second step is to code according to purpose. Based on research instruments that explore the profile and characteristics of increased entrepreneurship for Indonesian migrant workers, the code can be categorized into three main patterns: (1) the choice of being a migrant worker, (2) utilization of remittances, and (3) entrepreneurship. Each main pattern has indicators obtained from literature review and field observations. Furthermore, the relationship between the code and the results of the interview is identified so that quantitative results can be obtained from qualitative data. Quantitative is used as a measure of emphasis or how much the informant's perception of the criteria; if the criteria are mentioned more frequently and emphasized, the criteria are considered important.

The results of the analysis show that the choice of becoming migrant workers is dominated by high income in Hong Kong, which means that economic factors are still the main reason why someone chooses to become a migrant worker. The second reason is to improve the welfare of Indonesian labor migrants and their families. This reason is in line with the principle of altruism, namely the concern of Indonesian migrant workers towards their families, especially from the economic aspects that encourage them to become migrant workers. The third reason is because of low employment opportunities in the areas of origin.

The results of data processing using ATLAS.ti shows that entrepreneurship during the placement in Hong Kong is influenced by (1) training, (2) motivation, (3) assistance and (4) capital. The most dominant indicator for training is softskill followed by hardskill. Motivation is the second influential factor in entrepreneurship. Motivation is influenced by the IMW's desire to be independent, followed by entrepreneurial courage, and desire to be close to the family. These results indicate that the motivation for independence with the jargon of Becoming Employer or the desire not to become a worker is the most dominant indicator. 
Courage to become entrepreneurs is related to soft skills that must be nurtured. The desire to be close to the family has not become a dominant indicator because the migrant workers are concerned that they may not be able to generate a decent income when returning to their homeland. Besides, there is a change in the principle of life from "family first, income second" to "income first, family second"

Assistance is the third part in developing entrepreneurship which consists of study groups, institutions and marketing. The most dominant indicator is institutional, because Indonesian labor migrants really need the presence of both formal and informal institutions that provide intensive assistance. The institutional function is to provide space and opportunities for migrant workers to develop together. This institutional function is supported by the second indicator, study group, which shows how IMWs gather to develop their potential. The third indicator, marketing, has not become a dominant indicator because not all migrant workers who have participated in training have started a business. Capital becomes the last part in the entrepreneurship network for Indonesian labor migrants during the placement which is influenced by 2 indicators: savings and remittance allowances. Small Loan is not an indicator because for now there is no Small Loan facility that is utilized by Indonesian migrant workers in Hong Kong. Savings are allowances made by Indonesian labor migrants while remittance are those sent to families in the home country.

\section{Conclusions}

The position of migrant workers is mostly influenced by high income, while the use of remittances is influenced by both consumptive and productive activities. Network influence analysis shows that training is the most influential variable with soft skills and hard skills as its main components. Motivation is most influenced by the desire to be independent and the entrepreneurship courage. Assistance variable shows that institutions have the most important role. The capital variable shows that saving is a more important component.

This research is expected to be able to provide input to the government, especially the central government as the regulator to formulate regulations in the form of legislation, especially for increasing the human capital of Indonesian migrant workers from the time of pre-placement, placement and through to post-placement. To date, the placement stage seemed to be less prioritized because IMW are difficult to reach. However, education, training and mentoring can be done at this stage.

Regulations are implemented in policies followed by programs and budgeting in the form of entrepreneurial home development that involves all relevant stakeholders at the placement. The social engineering model that is integrated with the structured curriculum and materials followed by ongoing mentoring with a learning group system or Community Learning will encourage migrant workers who originally did 
not intend to take part in the training to participate and and develop the entrepreneurial characteristics.

\section{References:}

Efriyani, S. 2008. Model Tabungan Rumah Tangga (Sintesis Life Cycle Permanent Income). Semarang: Pasca Sarjana Undip.

Hardin, R. 2015. Rational Choice Explanation: Philosophical Aspects. International Encyclopedia of the Social \& Behavioral Sciences: Second Edition, 19, 896-900.

Mankiw, G. 2008. Microeconomic (Fifth Ed.). Mason: Cengage Learning.

Mattoo, A., Neagu, I.C. and Ozden, C. 2005. Brain waste? Educated immigrants in the US labor market. The World Bank.

Modigliani, F. and Ando, A.B. 1963. The Life Cycle Hypothesis of Saving: Aggregate Implications and Test.

Rahmat, J. 1999. Rekayasa Sosial: Reformasi atau Revolusi. Bandung: PT Remaja Rosda Karya.

Riswanto, A., Saribanon, E. and Gaffar, V. 2018. The importance of the cultural and gender outlook on consumer behavior studies: An Indonesian perspective. Arthatama Journal of Business Management and Accounting, 2(1).

Sato, Y. 2013. Rational choice theory. Sociopedia. isa., 1-10.

Tin, J. 2000. Life-cycle hypothesis, propensities to save, and demand for financial assets. Journal of economics and finance, 24(2), 110-121.

Williams, A.M. 2009. International migration, uneven regional development and polarization. European Urban and Regional Studies, 16(3), 309-322.

Yoon, H., Yun, S., Lee, J. and Phillips, F. 2015. Entrepreneurship in East Asian regional innovation systems: Role of social capital. Technological Forecasting and Social Change, 100, 83-95.

Zey, M. 1997. Rational choice theory and organizational theory: A critique. Sage Publications. 